\title{
Investigating Effects of Online Learning Management Tools on English Language Learning Among Undergraduate Students During COVID-19, at Shaheed Benazir Bhutto University, Shaheed Benazir Abad
}

\author{
Zeeshan Ali Rahu ${ }^{1} \quad$ Habibullah Pathan ${ }^{2}$ Sadia Memon ${ }^{3}$ \\ 1. MS Scholar, Mehran University of Engineering \& Technology, Jamshoro \\ 2.Associate Professor, Mehran University of Engineering \& Technology, Jamshoro \\ 3.Lecturer, Mehran University of Engineering \& Technology, Jamshoro
}

\begin{abstract}
The aim of this study is to investigate an 'effects of Online Learning Management Tools on English Language learning among undergraduate students at Shaheed Benazir Bhutto University. This study investigates the experiences and perceptions of teachers and the effects of online LMS on English language learners about online learning management tools. A mix-method and explanatory design was selected to achieve the objective of this study. This study applied mix method approach to collect data. The data was gathered in a descriptive form with respect to the scope and nature of the issue. The quantitative data used Qualtrics, and then the data was analyzed with SPSS statistical software package. In a qualitative phase, the semi-structured interviews were conducted from the participants through google meet application and data was analyzed through thematic analysis. This study concludes that, an idea of LMS is important in these day which actually reduces the distance communication problem among the specific participants. Different contents can be added such as video, audio, text documents and special types of class announcement. There are certain technical as well as student's personal reasons that create gap in online learning; such as network problems which most often disconnect the teachers and students to completely convey and understand the lecture.
\end{abstract}

Keywords: Online learning, management system, google classroom, English language learning, Covid-19.

DOI: $10.7176 / \mathrm{JEP} / 11-31-11$

Publication date: November $30^{\text {th }} 2020$

\section{Introduction}

\subsection{Online Learning Management System}

In this modern world, we live in an age of technology. Societies are mostly dependent on the technology. In addition, our small works depend on technology. Computers and internet are the important part of every field specifically in education. In education use of technology is necessary. Especially in second and foreign language learning and teaching. Computer base learning and teaching have the fundamental role in education. In this regard, it is famous as learning management tools (LMS). Further, LMS provides new learning and teaching ways such as Audio, Video, Cognitive and Communicative approaches. In this regard, LMS supports new learning skills more effectively than old methods of language teaching. LMS (Learning Management tools) is platform for the administration, official documentation, reporting daily activities, educational courses activities and teaching and learning programs.

Nowadays this world is known as a global era, so in this situation everyone wants to connect with each other because of different purpose for international business, education, politics, international computer communication and internet, sports, technology due to sharing information with each other. Therefore, it is need of international inhabitants who wants to communicate with each other for different purposes and they want to be associated and communicate and want to share their ideas. They keenly corporate with each other for their different daily routine purposes, so for that reason they want a special and international and global language for mutual communication which is equally and universally accepted with global citizen. It is a renowned proverb that "Necessity is the mother of invention". According to Anne Johnson in "The rise of English", (cited in Macalester international vol.22, p.131). The English language is an international language because 380 million people communicate in English as their native language or first language and 2/3 people use it as a second language in the world. According to Fauzia Shamim that the English is became a lingua franca and it plays a vital role for the development of socioeconomic development, educational, politics, international computer communication and internet, sports, technology and sharing information about different purpose and build up mutual association. No doubt number of people are also still associated with each other due to English language communication.

\subsection{Aim of the study}

The aim of this study is to investigate effects of Online Learning Management Tools which are putting effects on English language Learning of students. This study might help the learners and teachers by promoting distance 
learning through LMS.

\subsection{Objective of the study}

- To investigate effects of online learning management tools on English language learners

- To investigate the factors which effects on English language learners using LMS.

- To examine perceptions of teacher and students ease of English language over LMS

\subsection{Research questions}

- What are the effects of online learning management tools on English language learners?

- How do these factors effects on English language learners by using LMS?

- What are the perceptions of teacher and students about ease of English language over LMS?

\section{Literature review}

\subsection{Online learning management system in English language learning}

Learning management system tools have become popular in the education. In addition, education institutions expend more money to develop the computer facilities in the classrooms. Turban (2017) mentions that numerous researches have done on the effective use of the advantages of computer technology for students, limitations of LMS applications, role of teachers in LMS classroom, role of students in LMS classroom, teachers' perceptions about LMS and students' perceptions about LMS. Old language learning is the teacher centered. Students merely listen and follow the instructions of the teacher as it is. It is a boring and less productive method of teaching in language learning. Further, there is less interaction between the students and the teachers. The study further depicts that following the traditional methods institutions are limiting learning to only drills and practices. Further, Murcia (2001) mentions that computer programs guide and help extra supportive material in language classrooms. In addition, Murcia (2001) depicts that the use of computer programs in language classes students' cognitive and communicative develop more as compare to traditional methods of teaching and learning. In addition, on the one hand cognitive learning is individual that why student is responsible for his own learning. On the other hand, communicative approach improves communication in language learning.

\subsection{LMS implementation benefits}

According to Alghamdi \& Bayaga (2016) that LMS has certain benefits that come from by using it. It helps in stimulating pedagogical processes by blending learning practices and online learning environment. LMS courses provide an easier way of organizing the learning environment. The learning process becomes meaningful by providing core components such as course management tools and web-based communication resources (Mirriahi et al., 2015; Yildirim, Reigeluth, Kwon, Kageto, \& Shao, 2014). The main benefit of using LMS is simply that it provides an educator a tool to handle the learning process (Lochner et al., 2015).

\subsection{Hybrid and blended learning}

The classes is on the basis of the student and as well teacher appearance whereas the amount of time is reduced. In this method of learning the participants can learn and apply the practical work in lab whereas adding some online aspect can have reduced the efforts. It can enhance the time which provided online learning process and reduced being physically appeared in class. The fact to face communication and class activities can improve the teacher and student understanding whereas online aspect provides students facility over distance which is important in these days. One can easily combine the process of the fact to face learning and having online features of the information sharing with some online easy mechanism. The learners can easily enjoy the face to face communication meeting with the teacher as well having some flavor of the online management system which can provide the students ease of the usage having some relaxation. According to (Kavanagh.B, 2012) that Modern technology, modern English language teaching and modern English language teacher mostly prefer communicative language teaching methodology in their classrooms atmosphere.

\subsection{Google classroom}

\subsubsection{Definition of google classroom}

Beal (2017) narrates that Google Classroom is a tool which facilitates teacher and student's collaboration. Teacher can freely create and distribute assignments among students during an online classroom. It helps teachers to easily build groups in order to share assignments and announcements. Google Classroom is a very helpful source for learners to be active participant. According to Nagele (2017) teachers can create lessons planning which are students- centered. Students can be engaged in Google Classroom because it provides easy-to-use learning features with students of all categories. Google Classroom helps in engaging different categories of learners. It has certain advantages such as paperless, can be accessed everywhere and anywhere while having internet connection from some devices or having internet package. This process (internet connection) makes an easier way between students 
and teachers to communicate, giving feedback and personalized the learning. The learning feature of Google Classroom makes teachers to actively handle assignments and provide an appropriate feedback to students. It helps to teachers to handle students work efficiently. GC is a beneficial tool both for teachers and students because it provides them an easier and simple way of use.

\subsubsection{Moodle}

Moodle is a main source and it is a free learning management system. It is open source software for creating internet based lessons plan. Open source software source-code is the software which is along with source- code. This is distinctive feature of GC, and it is free of cost. Open- source software can bring change in the nature of software business and this change is effective and important in education. According to Kamkarhaghighi (2011) that open source code has brought changes in the method of using software by schools, institutions and students. It is operated system for educational purposes. Beaty and Ulasewicz (2006) say that the Modular Object Oriented Dynamic Learning Environment (MOODLE) is considered one of the famous and free software packages of LMS in universities of Europe. It is mainly based on a mode of learning as a social constructivism. This method of learning is in the form of interaction. The philosophy of this method can provide a better learning environment in the educational content. It makes new items for learners, and facilitates the students to communicate with fellows about content and teaching materials. Rice (2006) defines that the main difference between traditional class and social constructivism class is speech and debate. Social communication method within educational psychology is most important in order to create an environment for constructive interaction between teacher and students.

\section{Research design}

This study applied mix method approach to collect data. The data will be gathered in a descriptive form with respect to the scope and nature of the issue. The researcher has attempted to collect data to explore the effectiveness about an online learning management system for English language learning and teaching through LMS and for that purpose the researcher has used mixed method of data collection. This research also includes the pursuit to explore the factors that effect on online learning management tools at Shaheed Benazir Bhutto University SBA.

\subsection{Research setting \& Study sample}

The participators of the study are critically analyzing and selected through online classes, such as the faculty participators has given an online classes in last six months and the students participators selected on the behalf of that they have attended online classes approximately six months at a large number of students containing university. As the online teaching tools were introduced in the midst of March, 2020, so five months teaching experience was limited in study. This study conducted at Shaheed Benazir Bhutto University, SBA where large numbers of students are enrolled and where both traditional and online classes are provided to students. The total numbers of enrollment in university Is approximately 10,000 thousand and graduate and undergraduate course students are enrolling, where they are getting both traditional and online learning. This institution was selected due to the uncertain condition of pandemic COVID-19 in the year 2020 where the disease spread in all over the world and they could close all the institutions of the world. In this condition, every university conducted online classes so the researcher has intended to conduct this study and the diversity of opinions to make the study suitable and increase the quality of research.

Table: 4.1 Theme \#1 Impact of online learning at SBBU, SBA

\begin{tabular}{|c|c|c|}
\hline Themes \& Subthemes & Participants & Sample Responses \\
\hline $\begin{array}{l}\text { Subthemes: } \\
\text { Subtheme 1: Internet expenses, } \\
\text { financial background } \\
\text { Subtheme 2: most important } \\
\text { Subtheme3: Teachers training } \\
\text { Subtheme4: Connectivity issues } \\
\text { Subtheme } 5 \text { Mobile phone issues }\end{array}$ & $\begin{array}{l}\text { P-2 } \\
\text { P-3 } \\
\text { P-4 } \\
\text { P-5 }\end{array}$ & $\begin{array}{l}\text { 'LMS tool is good for those who can afford internet } \\
\text { expenses. } \\
\text { Students can get benefits from LMS tools but due to } \\
\text { financial background students are much worried about } \\
\text { using LMS tools'. (see: P1) } \\
\text { During online classes, every student is able to respond } \\
\text { with the course material lectures and presentations } \\
\text { assignments, and comments from other students. } \\
\text { Learner usually respond to those topics within the broader } \\
\text { conversation that most clearly speak to their individual } \\
\text { concerns. }\end{array}$ \\
\hline
\end{tabular}

\section{Analysis: 1}

The above responses showed that the biggest problems are connectivity of internet and it was the biggest problem for all of them which was faced by them during their online classes by almost all the faculty persons from the Shaheed Benazir Bhutto university, SBA. It is believed that learning management system tool is good for those who can afford internet expenses. Although it needs more improvements in terms of internet connectivity. There 
are issues such as network problems which most often disconnect the teachers while conveying and understanding the lecture. Another participant interviewed that I found it very beneficial because reason is that, we were asked by the higher education commission to conduct online classes during the pandemic days of covid-19. During those days it was quite hard to manage internet access and to involve all the students during online classes. Another participant said that LMS tool is good for those who can afford internet expenses. According to my view learners can get benefits from LMS tools but due to financial background students are much worried about using LMS tools, because for them LMS is new tool.

Table.4.2 Theme\#2Lackof Teacher's Training regarding use of LMS.

\begin{tabular}{|c|c|c|}
\hline $\begin{array}{l}\text { Theme 2: Lack of Techer's } \\
\text { Training regarding use of } \\
\text { LMS. }\end{array}$ & Participants & Sample Responses \\
\hline $\begin{array}{l}\text { Subthemes: } \\
\text { Subtheme 1: Lack of } \\
\text { teachers training } \\
\text { Subtheme 2: Need of } \\
\text { training } \\
\text { Subtheme 3: connectivity } \\
\text { issues } \\
\text { Subtheme: 4: }\end{array}$ & $\begin{array}{l}\text { P-2 } \\
\text { P-3 }\end{array}$ & $\begin{array}{l}\text { It was very well though training need to be extended as } \\
\text { practicing LMS is a complex phenomenon. } \\
\text { My LMS training experience is not productive because I feel } \\
\text { and understand there is just addition in my previous } \\
\text { knowledge. } \\
\text { There is no new and advance technique that could meet our } \\
\text { online teaching problems. } \\
\text { Academicians working in the universities irrespective of their } \\
\text { field of knowledge should be provided training on ICT to enjoy } \\
\text { its real benefits and ICT's proper utilization to excel in their } \\
\text { academic activities. } \\
\text { Top management should communicate through online } \\
\text { resources which will ultimately bring all the staff of } \\
\text { universities on services based on ICT. }\end{array}$ \\
\hline
\end{tabular}

\section{Analysis 2}

The above stated theme based on the question that brings very great importance. When the respondents were asked about their experiences in teacher training at university concerning the use of an LMS. The faculty members responded that in while their online classes using LMS is not a big issue for them they all agreed with this point. Although university trained all the teachers for using LMS tools and it was very informative training for all of them the training was conducted by senior Information technology teachers who all were aware about Learning Management System tools. the training $g$ was conducted during the days of corona virus by maintaining the social distancing and Trainers taught all aspects of LMS tools. Another participant participated that, the training was very well though training need to be extended as practicing LMS is a complex phenomenon. Another respondent responded that, Learning Management System provides a fine platform for both teachers and students as well. Fresh student's mainly graduate ones are having issues while interacting with LMS. Students should be provided prior information regarding LMS. According to the knowledge of another participant he proposed that My LMS training experience is not productive because I feel and understand there is just addition in my previous knowledge. There is no new and advance technique that could meet our online teaching problems.

Table 4.3 Theme\#3 Motivational factors that lead to utilize LMS.

\begin{tabular}{|c|c|c|}
\hline $\begin{array}{l}\text { Theme:3 Motivational factors } \\
\text { that lead to utilize LMS. }\end{array}$ & Participants & Sample Responses \\
\hline $\begin{array}{l}\text { Subthemes: } \\
\text { Subtheme 1: Resources of LMS } \\
\text { Subtheme 2: Covid factor } \\
\text { Subtheme 3: Lack of willingness } \\
\text { Subtheme 4:Lack of resources }\end{array}$ & $\begin{array}{l}\text { P-1 } \\
\text { P-2 } \\
\text { P-3 } \\
\text { P-4 }\end{array}$ & $\begin{array}{l}\text { LMS is paper less. In this way, there should be less use of } \\
\text { papers and other resources. } \\
\text { In my opinion, we can save around } 70 \% \text { of resources by } \\
\text { using LMS tools. } \\
\text { Learner autonomy seems to be related to motivation. A } \\
\text { lack of self- motivation is another barrier which resists } \\
\text { learners in managing the learning process. } \\
\text { Subsequently, their learning process would at the risk } \\
\text { Covid19 has been a leading factor. Before this, I was } \\
\text { hardly aware of its practice thought I know theoretically } \\
\text { about such things. }\end{array}$ \\
\hline
\end{tabular}

\section{Analysis:}

The above stated theme based on the question about some of the motivational factors and attitudes that lead teachers to utilize LMS in your classroom that brought very great importance. In this question participant 1 
responded that, first of all it is paper less. In this way, there should be less use of papers and other resources. In my opinion, we can save around $70 \%$ of resources by using LMS tools. Another participant said that, only one factor that is considered as the leading factor that is Covid19 has been a leading factor. After that, another participant answered that I couldn't get such sort of motivation. Actually due to pandemic situations taking life ahead we need to have such tools meanwhile maintaining social distancing. I was hardly aware of its practice thought i know theoretically about such things. Another participant said that, I have not found such motivational factor which ultimately lead me to exhibit my concern to utilize LMS online classes. being a teacher I still feel that the educational sector in my country will take enough time to be good at solving online teaching and learning problems.

Table 4.4 Theme\#04 Teachers challenges while teaching through online LMS.

\begin{tabular}{|l|l|l|}
\hline $\begin{array}{l}\text { Theme 4 Teachers } \\
\text { challenges while teaching } \\
\text { through online LMS. }\end{array}$ & $\begin{array}{l}\text { Participant } \\
\text { S }\end{array}$ & Sample Responses \\
\hline $\begin{array}{l}\text { Subthemes: } \\
\text { Subtheme 1: Connectivity } \\
\text { issues } \\
\begin{array}{l}\text { Subtheme 2: Lack of } \\
\text { training }\end{array}\end{array}$ & P-1 & $\begin{array}{l}\text { First network problem, less facilities of providing some devices } \\
\text { from our concerned institutions to continue online classes. } \\
\text { Heavy net packages, shortage of connectivity, shortage of } \\
\text { electricity, and intentionally or unintentionally an absence of } \\
\text { students many times in attending online classes. } \\
\text { ifficult }\end{array}$ \\
$\begin{array}{l}\text { Subtheme 4: Connectivity } \\
\text { issues } \\
\begin{array}{l}\text { Subtheme5: Unwillingness } \\
\text { presence of a teacher. These skills can easily be acquired by } \\
\text { physical learning as compare to distance learning. } \\
\text { Distance learning is unfamiliar environment for students } \\
\text { teaching }\end{array}\end{array}$ & P-3 & P-5
\end{tabular}

Analysis:

After the discussion about the learning management system tools, when the participants were asked about the challenges which were faced by the teachers as an EFL teacher while teaching online learning management tools. participant 1 said responded that, during their online classes internet issue is the major challenge while teaching using LMS. As we know as we live in Pakistan where there is a poor internet connection problems are there, these Learning Management System tools require internet with high bandwidths, that's why major challenge is internet connection along with unaffordable packages which are extremely heavy to manage for teachers and for students as well. Another issue is electricity load shedding. There is no proper time of load shedding, that's why we cannot deliver as per requirement.

Internet issue is the major challenge while teaching using LMS. As we know there is a poor internet connection, these LMS tools require internet with high bandwidths. Another issue is electricity load shedding. There is no proper time of load shedding, that's why we cannot deliver as per requirement. Another participant said that, I was not fully trained and although I myself faced big problem during connectivity because I belong to less developed rural area of Sindh, where there are mostly connectivity problems occur. besides that, Students found it difficult it to use too as a result it was challenging for me.one reason was that students mind was set on traditional methods was itself a challenge.

Table 4.5 Theme\# 5 Influence on your peers to utilize LMS in their online classes

\begin{tabular}{|c|c|c|}
\hline $\begin{array}{l}\text { Theme } 5 \text { Influence on } \\
\text { your peers to utilize LMS } \\
\text { in their online classes }\end{array}$ & Participants & Sample Responses \\
\hline $\begin{array}{l}\text { Subthemes } \\
\text { Subtheme 1: LMS was } \\
\text { hard to use. } \\
\text { Subtheme 2: Electricity } \\
\text { issues } \\
\text { Subtheme 3: LMS is } \\
\text { beneficial } \\
\text { Subtheme 4: Barrier in } \\
\text { communication } \\
\text { Subtheme 5: connectivity } \\
\text { issues }\end{array}$ & $\begin{array}{l}\text { P-1 } \\
\text { P-2 } \\
\text { P-3 } \\
\text { P-4 } \\
\text { P-5 }\end{array}$ & $\begin{array}{l}\text { It is very beneficial to use LMS if it is used properly. } \\
\text { Some LMS tools are very much clear and has more options and } \\
\text { they are easy to use. } \\
\text { Teachers and students are suggested and courage to find ICT as } \\
\text { a facilitator while communicating and collecting information. } \\
\text { They both can use effective use of digital devices such as: smart } \\
\text { phones, tablets, laptops, desktops etc. for the purpose of } \\
\text { communication So teachers as well as students will not face any } \\
\text { difficulty about the usage of LMS. } \\
\text { My LMS teaching is not productive that effect on my students } \\
\text { learning. }\end{array}$ \\
\hline
\end{tabular}

Analysis:

This was the last question that was asked about the influence that teacher feel that they have made on their peers to utilize LMS in their classroom environments. Participant 1 responded that, it is very beneficial to use LMS if it 
is used properly. Some LMS tools are very much clear and has more options and they are easy to use. So that teachers as well as students will not face any difficulty about the usage of LMS. Participant 2 responded that, it was extremely difficult for him to Use LMS and he will not prefer to use LMS in classrooms as well.

\section{Analysis of quantitative data}

The quantitative research used questionnaire as a tool to collect data from targeted area at Shaheed Benazir Bhutto University, SBA. Total 100 participants participated in this study. This research is going to investigate the effects of online learning management tools in English language learning among undergraduate students at SBBU, SBA. The researcher has conducted mixed method through adopt questionnaire which is used by different researcher in different research. Here are five influential factors and they may affect the learners during their online learning management system and the perceptions and experiences of teachers as well, so that researcher has conducted mixed method research through questionnaire that consist on twenty close-ended questions. Each four question are related to different variables and these four questions were followed a research question which are set by researcher to conduct research to collect true data with the help of SPSS software. These five factors1) Compatibility 2) Ease of Use, 3) Intention to use E-learning4) Image 5), Intention to use E-learning.

Descriptive Statistics

Factor: 1 Compatibility

\begin{tabular}{|l|r|r|r|r|r|r|}
\hline & N & Minimum & Maximum & \multicolumn{2}{|c|}{ Mean } & $\begin{array}{c}\text { Std. } \\
\text { Deviation }\end{array}$ \\
\cline { 2 - 7 } & Statistic & Statistic & Statistic & Statistic & \multicolumn{1}{|c|}{$\begin{array}{c}\text { Std. } \\
\text { Error }\end{array}$} & \multicolumn{1}{|c|}{ Statistic } \\
\hline $\begin{array}{l}\text { Using a LMS is compatible with all aspects } \\
\text { of my learning. }\end{array}$ & 97 & 1.00 & 5.00 & 3.4536 & .10969 & 1.08032 \\
I think that using a LMS fits well with the & 96 & 1.00 & 5.00 & 3.6562 & .09108 & .89240 \\
way I like to learn. & 97 & 1.00 & 5.00 & 3.6082 & .09560 & .94159 \\
Using a LMS fits into my learning style. & 97 & 1.00 & 5.00 & 3.4845 & .10165 & 1.00118 \\
LMS is appropriate for my profession in all \\
$\begin{array}{l}\text { aspects. } \\
\text { Valid N (listwise) }\end{array}$
\end{tabular}

Descriptive Statistics

Factor: 2 Ease of Use

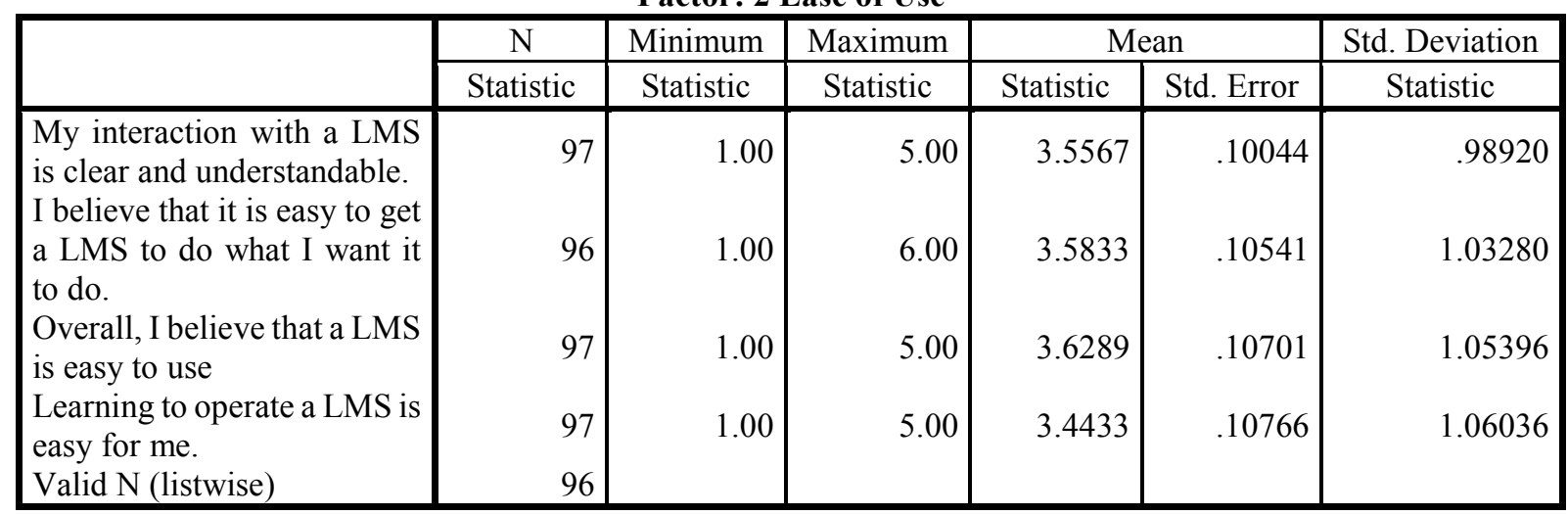




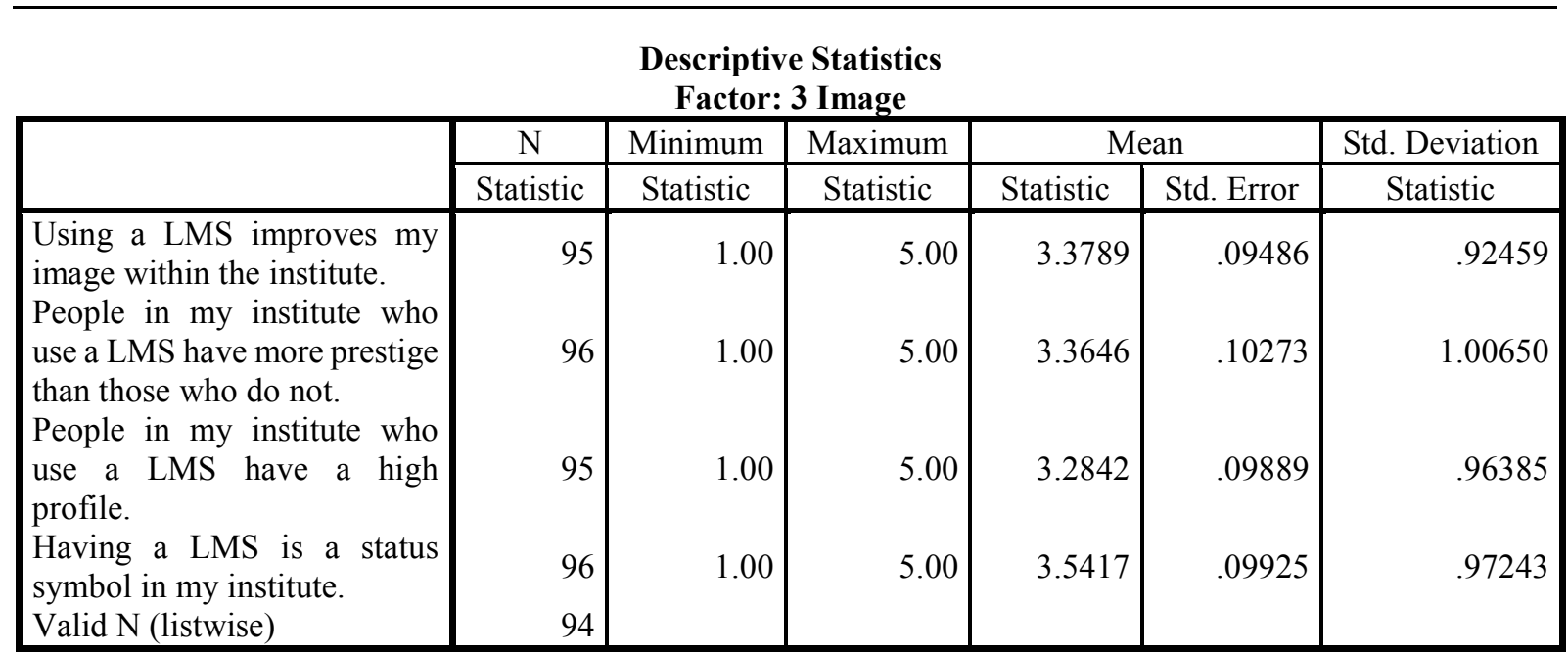

Factor: 4 Attitude to e-Learning Descriptive Statistics

\begin{tabular}{|l|r|r|r|r|r|r|}
\hline & \multicolumn{1}{|c|}{$\mathrm{N}$} & \multicolumn{1}{c|}{ Minimum } & \multicolumn{1}{|c|}{ Maximum } & \multicolumn{2}{|c|}{ Mean } & Std. Deviation \\
\cline { 2 - 7 } & Statistic & Statistic & Statistic & Statistic & Std. Error & Statistic \\
\hline $\begin{array}{l}\text { Studying through e-learning } \\
\text { is a wise idea. }\end{array}$ & 96 & 1.00 & 5.00 & 3.8125 & .10914 & 1.06931 \\
$\begin{array}{l}\text { I am positive towards e- } \\
\text { learning. } \\
\begin{array}{l}\text { A web-based learning system } \\
\text { provides an attractive learning } \\
\text { environment. }\end{array}\end{array}$ & 95 & 1.00 & 5.00 & 3.7895 & .11485 & 1.11941 \\
$\begin{array}{l}\text { Overall, I like using web- } \\
\text { based learning. } \\
\text { Valid N (listwise) }\end{array}$ & 96 & 1.00 & 5.00 & 3.6146 & .10510 & 1.02977 \\
\hline
\end{tabular}

Factor :05 Intention to use E-learning Descriptive Statistics

\begin{tabular}{|l|r|r|r|r|r|r|}
\hline & \multicolumn{1}{|c|}{$\mathrm{N}$} & \multicolumn{1}{|c|}{ Minimum } & \multicolumn{1}{c|}{ Maximum } & \multicolumn{2}{|c|}{ Mean } & Std. Deviation \\
\cline { 2 - 7 } & Statistic & Statistic & Statistic & Statistic & Std. Error & Statistic \\
\hline $\begin{array}{l}\text { I intend to use the LMS to } \\
\text { study. }\end{array}$ & 95 & 1.00 & 5.00 & 3.5368 & .09677 & .94318 \\
$\begin{array}{l}\text { I intend to increase my use of } \\
\text { the LMS in the future. }\end{array}$ & 96 & 1.00 & 5.00 & 3.6042 & .11611 & 1.13767 \\
$\begin{array}{l}\text { Having used the LMS, I } \\
\text { would recommend it to my } \\
\text { colleagues to use it for study } \\
\text { purposes. }\end{array}$ & 95 & 1.00 & 5.00 & 3.7158 & .10546 & 1.02794 \\
$\begin{array}{l}\text { I intend to be a heavy user of } \\
\text { e-learning system. }\end{array}$ & 96 & 1.00 & 5.00 & 3.4792 & .10469 & 1.02576 \\
\hline \begin{tabular}{l} 
Valid N (listwise) \\
\hline
\end{tabular}
\end{tabular}

\subsection{Discussion of the results of the Questionnaire}

There are some important issues related to the online learning management system tools relevant to the effectiveness of technology. The results from the questionnaires indicated that, online learning management tools cannot assure the learning of students. The results showed that if the online learning management are used in proper way through this it can bring lot of benefits throughout learning process. It is the source which can be used by students because it assists them to resolve learning difficulties. Number of the students agreed on that their interaction with online Learning Management System is clear and understandable, and it effects on their learning process positively. Most of the students said that online LMS tools is easy to use according to their online classes during the days of covid-19, but one of the issues that was the major concern is connectivity issues it was one of the prominent issues faced by all of them. In other words, according to the participant's responses number of the 
students agreed that after using that online LMS tool I Would recommend it to my colleagues to use it for the purpose of attending online webinars, seminars, workshops etc. Finally, online LMS tools offers understandable contribution and production, that supports students to advance intellectual abilities, makes knowledge more learner-centered, encourages learners' autonomy and assists them with more learner's motivation, willingness to learn, proficiently as well.

\section{Discussion}

The main goal of the current study was to better understand the potential and use of technology for enhancing collaboration and student engagement in online settings and the factors that influence the selection of collaborative technology tools for collaborative eLearning activities in online courses. The findings of the study confirm that technology has the potential to enhance collaboration and student engagement in online settings by offering opportunities for collaboration and enable students who are spread geographically to engage in collaborative eLearning activities, which could never be achieved without the use of collaborative technology tools. Despite the instructional and technical challenges, the study shows that collaborative technology tools can have a positive impact on student engagement by offering opportunities for communication, interaction, and collaboration in online learning. The feature which provide by the synchronous system is to make easy for the students when they communicate with others during teaching and learning process. However synchronous environment does not support availability all the time for learners. It also provides online teaching and learning process which makes easy to learn and grow the academic excellence time by time. In this process of learning and communication participants in the class room having some scheduled hours.

\section{Conclusion}

To conclude, an idea of LMS is important in these day which actually reduces the distance communication problem among the specific participants. Different contents can be added such as video, audio, text documents and special types of class announcement. One of the most affecting factors that effects on students during online learning management system is connectivity issues and for teacher's lack of training. Moreover, there is another issue that was faced by the students that is use ability of such tools. The synchronous environment needs to involve both students and teacher in directly involvement which basically is real-time involvement. In which course facilities fixes a time to manage and control the activities of the student and academic issues communication and discussion is being done online. In short, although LMS is good and very supportive tool in perspective of online learning. The experience of students remained fair during the days of COVID-19.

\section{References}

Hashmi, N. A. (2016). Computer-assisted language learning (CALL) in the EFL classroom And its impact on effective teaching-learning process in Saudi Arabia. International Journal of Applied Linguistics and English Literature, 5(2), 202-206.

Noval, J. J. (2016). A Mixed Methods Study on the Usage of a Learning Management System by Allied Health Faculty (Doctoral dissertation, Northcentral University).

Towne, T. (2018). Exploring the Phenomenon of Secondary Teachers Integrating the LMS Canvas in a BlendedLearning Course.

Roche, M. (2014). Developing children's critical thinking through picture books: Aguide For primary and early years students and teachers. Routledge.

Lauricella, Wartella, E. (2017). The "new" technology environment: The role of content And context on learning and development from mobile media. In Media exposure during infancy and early childhood (pp. 123).Springer, Cham.

Iftakhar, S. (2016). Google classroom: what works and how. Journal of Education and Social Sciences, 3(1), $12-$ 18.

Feizabadi, N., Aliabadi, K., \&Ahmadabadi, M. N. (2016). The impact of English learning software Moodle. International Journal of Humanities and Cultural Studies (IJHCS) ISSN 2356-5926, 1(1), 1427-1437.

Moghaddam Zanjani, F. V., \& Ramazani, M. (2012). Investigation of e learning acceptance inteaching English language based on TAM Model. ARPN Journal of Systems and Software, 2(11).

Almekhlafi, A. G. (2016). The effect of computer assisted language learning(CALL) on United Arab Emirates English as a foreign language (EFL) school students' achievement and attitude. Journal of Interactive learning research, 17(2), 121-142.

Yang \& Chen, Y. J. (2007). Technology-enhanced language learning: Acase study. Computers in human behavior, 23(1), 860-879.

Siddiquah, A., \&Salim, Z. (2017). The ICT facilities, skills, usage, and the problems faced By the students of higher education. EURASIA Journal of Mathematics, Science and Technology Education, 13(8), 4987-4994. 